\title{
Kontribusi Pendidikan Islam Menuju Indonesia Maju
}

\author{
Usri \\ Sekolah Tinggi Agama Islam Negeri Majene \\ Email: usri@stainmajene.ac.id
}

\begin{abstract}
This study aims to discuss about the contribution of Education in particular Islamic Education in welcoming Indonesia forward. The theme becomes urgent to be studied to explore further about Islamic education in the history of the Indonesian people who have trodden more than half a century of age. The method used in this research is literature study. Based on the results of the study found the active role of the old order government, the new order and reform through several strategic policies to foster Islamic education in Indonesia. The position of Islamic education as an educational institution, as subjects and values of Islamic Education contained in the National Education System. Until the contribution of Islamic Education in the development of quality human resources towards Advanced Indonesia. Islamic education is part of the Indonesian nation and the progress of the Indonesian people has a strong relationship with the dynamics of Islamic education.
\end{abstract}

Keywords: Education, Islam, Indonesia

\begin{abstract}
ABSTRAK
Penelitian ini bertujuan untuk membahas tentang kontribusi Pendidikan khususnya Pendidikan Islam dalam menyongsong Indonesia maju. Tema tersebut menjadi urgen untuk dikaji untuk menelisik lebih jauh tentang pendidikan Islam dalam menorehkan sejarah bangsa Indonesia yang telah menginjak usia lebih dari setengah abad. Metode yang digunakan
\end{abstract}


dalam penelitian ini adalah studi pustaka. Berdasarkan hasil penelitian ditemukan peran aktif pemerintah orde lama, orde baru serta reformasi melalui beberapa kebijakan strategis untuk menumbuhkan pendidikan Islam di Indonesia. Kedudukan pendidikan Islam sebagai lembaga pendidikan, sebagai mata pelajaran serta nilai-nilai Pendidikan Islam yang terkandung dalam Sistem Pendidikan Nasional. Hingga kontribusi Pendidikan Islam dalam pembangunan sumber daya manusia yang berkualitas menuju Indonesia Maju. Pendidikan Islam bagian dari bangsa Indonesia dan maju mundurnya bangsa Indonesia memiliki relasi yang kuat dengan dinamika pendidikan Islam.

Kata kunci: Pendidikan, Islam, Indonesia

\section{PENDAHULUAN}

\section{Latar Belakang}

Pendidikan diartikan secara berbeda-beda oleh banyak kalangan yang tentunya dipengaruhi pandangan dunia masing-masing. Namun pada dasarnya semua yang pandangan itu bertemu dalam kesimpulan awal bahwa pendidikan merupakan satu proses penyiapan generasi muda untuk menjalankan kehidupan dan memenuhi tujuan hidupnya secara lebih efektif dan efisien. ${ }^{1}$

Pendidikan jika dikaitkan dengan Islam maka pengertian pendidikan Islam mengandung pandangan dasar Islam berkenaan dengan manusia dan signifikansi dengan ilmu pengetahuan. Pendidikan Islam merupakan pendidikan yang seluruh komponen atau aspeknya didasarkan pada ajaran Islam. Pendidikan Islam memiliki visi menjadi lembaga yang kuat, berwibawa, efektif, dan kredibel untuk mewujudkan cita-cita Islam. ${ }^{2}$

${ }^{1}$ Azyumardi Azra, Pendidikan Islam; Tradisi dan Modernisasi di tengah Tantangan Millenium III. (Cetakan ke-2, Jakarta: Kencana, 2014), h.6-7

${ }^{2}$ Abuddin Nata, Ilmu Pendidikan Islam, (Cetakan ke-3, Jakarta: Kencana, 2016), h. 44. 
Pendidikan adalah suatu proses perubahan yang berkelanjutan menuju pada suatu kebaikan. Perubahan yang dihasilkan oleh pendidikan sifatnya ovelusioner dan tetap. Dengan demikian terlihat jelas arti penting pendidikan bagi suatu masyarakat menuju sebuah kemajuan. ${ }^{3}$

Pendidikan Islam yang merupakan bagian dari Sistem Pendidikan Nasional Indonesia, selayaknya ikut berkontribusi untuk mewujudkan citacita kemerdekaan Negara Republik Indonesia yakni mencerdaskan kehidupan bangsa. Namun, Ikhtiar untuk membangun manusia Indonesia termasuk juga di dalamnya manusia Indonesia dari masa ke masa selalu menemui tantangan dan hambatan, baik internal maupun eksternal, dalam maupun luar negeri.

Penentu kemajuan suatu bangsa adalah adalah gerasi muda yang berkualitas. Namun, generasi muda yang berkualitas ditentukan oleh sistem pendidikan yang berkualitas pula. Fakta sejarah membuktikan bahwa bangsa yang telah mencapai kesejahteraan adalah bangsa yang meletakkan pondasi pembangunannya melalui pendidikan. Melalui sumber daya manusia yang memadai mereka dapat mencapai kesejahteraan dan kemajuan bangsanya.

Salah satu hal yang menyebabkan ketertinggalan bangsa Indonesia dari bangsa-bangsa maju di belahan dunia lain adalah kurangnya keberpihakan pemerintah sebagai penentu kebijakan sekaligus pelayan masyarakat pada bidang pendidikan. ${ }^{4}$ Oleh sebab itu, kegagalan pemerintahan suatu bangsa untuk memajukan bangsa apabila lemah dalam menyokong bidang pendidikan. Pendidikan merupakan kunci untuk mengembangakan pengetahuan dan kualitas kemampuan masyarakat suatu bangsa. Dukungan terhadap pentingnya kontribusi pendidikan dalam memajukan bangsa Indonesia sebagai bangsa yang besar di antara negaranegara di dunia ini, sesungguhnya telah tertuang di dalam Undang-Undang Dasar (UUD) 1945, yang mengamanatkan bahwa, pendidikan merupakan hak dan kewajiban bagi seluruh warga Indonesia. Oleh sebab itu,

\footnotetext{
${ }^{3}$ Halik, Abdul. "Paradigma Pendidikan Islam dalam Transformasi Sistem Kepercayaan Tradisional." AL-ISHLAH: Jurnal Pendidikan Islam 14.2 (2016), h. 141.

${ }^{4}$ Hanafie, D., \& Hali, A. (2015). Masalah Putus Sekolah Dan Pengangguran.
} 
pendidikan seharusnya menjadi prioritas utama dalam proses keseluruhan pembangunan nasional. ${ }^{5}$

Indonesia saat ini telah berumur lebih dari setengah abad sejak deklarasi kemerdekaannya, jadi sudah selayaknya Indonesia bisa berdiri sejajar dengan negara-negara maju dunia. Berdasarkan uraian latar belakang di atas, penulis tertarik untuk menelisik lebih jauh tentang kontribusi pendidikan utamanya pendidikan Islam di Indonesia dalam menyongsong Indonesia maju.

\section{Permasalahan}

Kajian dalam penelitian ini menelaah tentang dinamika Pendidikan Islam di Indonesia dan kontribusi terhadap pembangunan dan kemajuan bangsa. Adaun yang menjadi rumusan masalah, adalah:

1. Bagaimana dinamika pendidikan Islam di Indonesia?

2. Bagaimana Kedudukan Pendidikan Islam terhadap Pendidikan Nasional?

3. Bagaimana Kontribusi Pendidikan Islam menuju Indonesia Maju?

\section{PEMBAHASAN}

\section{Dinamika Pendidikan Islam di Indonesia}

1. Pendidikan Islam pada masa orde lama

Orde Lama merupakan masa pemerintahan Presiden Soekarno sejak masa kemerdekaan tahun 1945 hingga tahun 1965. Istilah orde lama dicetuskan ketika pemerintahan Soeharto yang dikenal dengan masa Orde Baru yang merupakan pemerintahan setelah Orde Lama. ${ }^{6}$ Adapun terkait kebijakan pemerintah orde lama tentang pelaksanaan pendidikan Islam tidak bisa terlepas dari Sistem Pendidikan Nasional saat itu.

Semasa pemerintahan orde lama terjadi pertarungan antara kepentingan ideologi komunis, nasionalis sekuler dan kelompok agama

\footnotetext{
${ }^{5}$ Muhardi, Kontribusi Pendidikan Dalam Meningkatkan Kualitas Bangsa Indonesia, Jurnal mimbar, Volume XX No. 4 Oktober - Desember 2004, h. 480

${ }^{6}$ https://id.wikipedia.org/wiki/Orde_Lama, diakses tanggal 7 November 2019
} 
Islam karena presiden Soekarno adalah tokoh yang menganut ideologi nasionalis yang berbasis ke Indonesiaan dan kultural. Dalam posisinya itu, ia terkadang dekat dengan kelompok Islam dan terkadang dekat dengan kelompok sekularis-komunis. ${ }^{7}$ Akan tetapi, pasca kemerdekaan Negara Indonesia, pemerintah mulai memberikan perhatian serius kepada pendidikan agama termasuk juga di dalamnya pendidikan Islam, baik itu di sekolah negeri maupun sekolah swasta. Hal tersebut terbukti dengan diadakannnya pembicaraan terkait garis besar pendidikan nasional oleh Badan Pekerja Komite Nasional Pusat pada tanggal 27 Desember 1945. Output dari pembicaraan rincian dari rumusan garis besar pendidikan nasional dilaporkan oleh panitia di antaranya adalah diusulkannya tentang pendidikan agama.

Adapun usulan tersebut adalah sebagai berikut: Pertama, pelajaran agama dalam semua sekolah diberikan pada jam pelajaran sekolah. Kedua, pemerintah wajib membayar para guru. Ketiga, pada Sekolah Dasar, pendidikan agama mulai diberikan di kelas IV. Keempat, pendidikan agama diselenggarakan seminggu sekali pada jam tertentu. Kelima, guru diangkat oleh Departemen Agama. Keenam, paraguru agama juga diwajibkan cakap dalam pendidikan umum. Ketujuh, buku pendidikan agama disiapkan oleh pemerintah. Kedelapan, diadakannya pelatihan bagi guru agama. Kesembilan, perbaikan kualitas pesantren serta madrasah dan sejenisnya. Kesepuluh, pengajaran bahasa Arab tidak dibutuhkan. Ketentuan tersebut selanjutnya menjadi acuan bagi pelaksanaan Pendidikan Agama Islam di sekolah umum. ${ }^{8}$

Perkembangan pendidikan Islam di Indonesia pada masa orde lama sangat erat kaitannya dengan peran Departemen Agama yang resmi berdiri pada Tanggal 3 Januari 1946. Departemen Agama memperjuangkan politik pendidikan Islam di Indonesia secara berkelanjutan. Salah satu tugas

${ }^{7}$ Abuddin Nata, Manajemen Pendidikan: Mengatasi Kelemahan Pendidikan di Indonesia, (Jakarta: Kencana, 2005), h. 14.

${ }^{8}$ Ismail, Politik Pendidikan Islam Orde Lama 1945-1965 (Study Kebijakan Pemerintah dalam Penyelenggaraan Pendidikan Islam), Jurnal Kabilah Vol. 1 No. 1 Juni 2016, h. 150 
Departeman Agama adalah mengurus masalah pendidikan Agama di sekolah Umum, Madrasah, Pesantren dan sejenisnya serta di kelola oleh suatu unit khusus yaitu bagian pendidikan yang bertugas urusan pelajaran dan pendidikan agama Islam dan Kristen, urusan pengangkatan guru agama serta pengawasan pelajaran. ${ }^{9}$

Adapun kebijakan resmi pertama tentang pendidikan agama di sekolah umum, dicantumkankan dalam Undang-Undang Pendidikan tahun 1950 Nomor 4 yang resmi disahkan pada tanggal 2 April 1950 pasal 20 ayat 1 dan 2 mengatur tetang penyelenggaraan pendidikan agama di sekolah negeri, dan orang tua murid mempunyai hak untuk menetapkan anaknya mengikuti atau tidak pelajaran tersebut. Adapun tata cara penyelenggaraan Pendidikan Agama di sekolah negeri diatur melalui menteri pendidikan, pengajaran dan kebudayaan bersama menteri agama. ${ }^{10}$

Selain itu, lahirnya kebijakan dua Menteri yakni Menteri Agama juga Menteri Pendidikan dan Pengajaran yang menetapkan bahwa Pendidikan Agama mulai diajarkan di kelas IV SR sampai kelas VI juga merupakan salah bagian kontribusi pemrintah masa orde lama terhadap pendidikan Islam. $^{11}$

2. Pendidikan Islam Pada Masa Orde Baru

Orde Baru merupakan masa pemerintahan di Indonesia yang terjadi sejak 11 Maret 1966 hingga 21 Mei 1998 yakni saat peralihan presiden dari Soeharto ke Habibie. Peralihan pemeritahan dari orde lama ke Orde Baru membawa konsekuensi perubahan strategi politik tak terkecuali dengan kebijakan pendidikan nasional. Perubahan kebijakan pendidikan nasional dengan beralihnya pengaruh komunisme ke arah pemurnian Pancasila melalui rencana pembangunan nasional berkelanjutan memberikan corak

${ }^{9}$ Faisal Mubarak, Perkembangan Kebijakan Pendidikan Islam Indonesia, Jurnal: Ta'lim Muta'allim, Vol. 4, No. 8, tahun 2015, h.238

${ }^{10}$ Mohammad Kosim, Kebijakan Pendidikan Agama Islam di Sekolah pada Masa Orde lama, Jurnal Karsa, Vol. 22 Nomor 1, Juni 2014, h. 11

${ }^{11}$ Aisyah Nursyarif, Pendidikan Islam di Indonesia dalam Lintasan Sejarah (Perspektif Kerajaan Islam), Jurnal Lentera Pendidikan Vol. 17 No.2 Desember 2014, h. 264 
baru pula bagi kebijakan Pendidikan Agama Islam. Pergeseran kebijakan, dari murid berhak tidak ikut serta dalam pelajaran agama apabila mereka menyatakan keberatannya, menjadi semua murid wajib mengikuti pendidikan agama mulai dari sekolah dasar hingga perguruan tinggi. ${ }^{12}$

Kebijakan pemerintah terkait dengan Pendidikan Islam saat memasuki masa orde baru menurut Abuddin Nata dalam St. Hasniati mengatakan bahwa pada tahun 1966 MPRS mengeluarkan ketetapan nomor XXVII/MPRS/1966 Bab I pasal I, bahwa pendidikan agama menjadi mata pelajaran wajib di sekolah mulai dari sekolah dasar hingga perguruan tinggi negeri. Hal tersebut ditegaskan melalui TAP MPR Nomor IV /MPR/1978 yang memuat Garis-Garis Besar Haluan Negara bahwa pelaksanaan pendidikan agama mulai dari sekolah dasar hingga perguruan tinggi. Kebijakan lebih rinci dapat dilihat pada keputusan pemerintah Nomor 08/c/u/1975 yang menyatakan bahwa pendidikan agama di sekolah dasar sampai sekolah menengah merupakan salah satu bidang studi. Bidang studi pendidikan agama diajarkan tiap minggu 2 jam untuk kelas 1, II, III SD 3 jam untuk kelas IV, V, VI serta 2 jam untuk SMP dan SMA, Nilai Pendidikan Agama bahkan menjadi penentu kenaikan kelas jika tidak mencapai nilai sekurang-kurangnya enam. ${ }^{13}$

Adapun kebijakan lain terkait pendidikan Islam pada masa Orde Baru yakni: pertama, Lahirnya SKB Tiga Menteri tentang Peningkatan Mutu Pendidikan Madrasah, hal tersebut menandai masuknya Sistem Pendidikan Islam ke dalam Sistem Pendidikan Nasional. Sebagai realisasi dari SKB Tiga Menteri, Departemen Agama menetapkan kurikulum standar untuk dijadikan acuan oleh madrasah. Kedua, wujud nyata perhatian pemerintah dalam pengembangan madrasah disetarakan dengan sekolah umum yakni dengan lahirnya Undang-Undang Nomor 2 Tahun 1989 tentang Sistem Pendidikan Nasional. Orde Baru yang merupakan Orde Konstitusional dan Orde Pembangunan yang bertujuan membangun manusia

${ }^{12}$ Sofyan Rofi. Sejarah Pendidikan Islam di Indonesia. Jakarta; Deepublish, 2016. hal, 43

${ }^{13}$ St. Hasniyati Gani Ali, Kebijakan Pemerintah terhadap Pembinaan Pendidikan Islam, Jurnal Al-Ta'dib Vol. 8 No. 2, Juli-Desember 2015, h. 103 
seutuhnya serta menyeimbangkan antara jasmani dan rohani untuk mewujudkan kehidupan yang lebih baik yang dirumuskan dalam UndangUndag Nomor 2 Tahun 1989 tentang Sistem Pendidikan Nasional. ${ }^{14}$

3. Pendidikan Islam pada Era Reformasi

Reformasi merupakan istilah yang amat populer pada masa krisis dan menjadi kata kunci dalam membenahi seluruh tatanan kehidupan berbangsa dan bernegara di tanah air Indonesia, termasuk reformasi di bidang pendidikan. Reformasi juga membawa angin segar perbaikan bagi pendidikan Islam, dengan dikeluarkannya beberapa kebijakan pemerintah terkait pendidikan Islam itu sendiri.

Era reformasi dimulai yang pada Tahun 1998 melahirkan begitu banyak pasal dalam Undang-Undang serta peraturan pemerintah yang mengatur tentang pendidikan Islam. Salah satu di antaranya adalah UndangUndang Nomor 20 tahun 2003, di dalam UU tersebut setidaknya ada 3 hal yang terkait dengan pendidikan Islam. Pertama, secara kelembagaan pemerintah mengakui keberadaan Lembaga pendidikan madrasah yang setara dengan sekolah umum, demikian pula dengan keberadaan Pesantren Diniyah Raudhatul Athfal. Kedua, diakuinya keberadaan pelajaran Pendidikan Agama Islam sebagai mata pelajaran, di sekolah-sekolah dan madrasah-madrasah. Ketiga, dalam sistem pendidikan nasional terdapat seperangkat nilai-nilai Islam. ${ }^{15}$

Wujud lain dari keseriusan pemerintah untuk meningkatkan kualitas Pendidikan Islam di Indonesia pada era Reformasi terlihat dari terbitnya Peraturan Pemerintah Nomor 55 tahun 2007 tentang pendidikan agama dan keagamaan. Kebijakan kebijakan tersebut diharapkan mampu memberikan perubahan dari sisi manajerial dan proses pendidikan Islam. Bersamaan dengan hal tersebut, Perkembangan sosial budaya yang begitu massif

\footnotetext{
${ }^{14}$ Sofyan Rofi. Sejarah Pendidikan Islam di Indonesia, op cit, h. 44

${ }^{15}$ H. Haidar Putra Daulay, M.A. Pendidikan Islam dalam Sistem Pendidikan Nasional di Indonesia. Jakarta: Kencana Prenada Group, 2012, h.7
} 
ditandai dengan kemajuan teknologi, semakin menguatkan pentingnya pendidikan karakter melalui pendidikan agama di sekolah. ${ }^{16}$

\section{Kedudukan Pendidikan Islam terhadap Pendidikan Nasional}

Pendidikan Islam dalam Sistem Pendidikan Nasional tidak bisa dipisahkan satu sama lain, hal tersebut dapat dilihat dari tiga hal sebagai berikut ${ }^{17}$ :

1. Pendidikan Islam sebagai lembaga pendidikan,

Pendidikan Islam sebagai lembaga pendidikan di Indonesia, diatur dalam pasal 17 tentang Pendidikan Dasar, pasal 18 tentang Pendidikan Menengah, pasal 20 tentang Pendidikan Tinggi untuk pendidikan formal. Adapun pendidikan nonformal dalam pasal 26 terdiri dari lembaga kursus, lembaga pelatihan, kelompok belajar, pusat kegiatan belajar masyarakat, dan majelis taklim, serta satuan pendidikan sejenis. Pasal 2827 mengatur tentang pendidikan informal, pasal 28 tentang pendidikan Usia Dini, hingga pasal 30 tentang pendidikan keagamaan

2. Pendidikan Islam sebagai mata pelajaran

Pendidikan Islam sebagai mata pelajaran diwujudkan dalam kurikulum setiap jenjang pendidikan yang wajib memuat Pendidikan Agama dan Pendidikan Kewarganegaraan. Undang-Undang Sistem Pendidikan Nasional menyebutkan bahwa pendidikan agama adalah hak setiap peserta didik pada setiap pendidikan.

3. Pendidikan Islam sebagai sistem nilai

Nilai-nilai pendidikan Islam dalam Sistem Pendidikan Nasional adalah nilai yang membawa kemaslahatan dan kesejahteraan bagi seluruh makhluk sebagai wujud dari konsep rahmatan lil alamin, demokratis, agalitarian, dan humanis. Nilai-nilai tersebut antara lain termuat dalam UU No. 20 tahun 2003 yang menyebutkan bahwa fungsi pendidikan nasional adalah untuk mengembangkan kemampuan dan

\footnotetext{
${ }^{16}$ Miftahol Jannah, Bachtiar Adi Saputra, Aminatus Sya'adah, Choirul Mahfud, Sejarah reformasi pendidikan Islam di Indonesia, Ta'dibuna Vol.8 No.1, April 2019, h. 43

${ }^{17}$ H. Haidar Putra Daulay, M.A. Pendidikan Islam dalam Sistem Pendidikan Nasional di Indonesia, op cit, h. 11-15
} 
membentuk watak serta peradaban bangsa yang bermartabat. Pendidikan nasional juga bertujuan untuk mengembangkan potensi peserta didik agar menjadi manusia yang beriman dan bertaqwa kepada Tuhan Yang Maha Esa.

Selain beberapa hal yang telah disebutkan di atas, dalam UndangUndang Sistem Pendidikan Nasional No. 20 tahun 2003 yang merupakan landasan operasional pelaksanaan Pendidikan Nasional di Indonesia, dapat dilihat kedudukan Pendidikan Islam yang semakin kuat di antaranya pada pasal 12 yang menekankan hak pengajaran Pendidikan Agama kepada peserta didik dan diajarkan oleh guru agama sesuai dengan agama masingmasing peserta didik tersebut. Selajutnya pada pasal 37 ayat 1 tentang muatan wajib kurikulum di sekolah yang salah satunya adalah Pendidikan Agama. Hal tersebut berarti setiap guru Pendidikan Agama Islam mempunya landasan yang kuat untuk mengembangakan pembelajaran Pendidikan Islam di sekolah. ${ }^{18}$

\section{Kontribusi Pendidikan Islam menuju Indonesia Maju}

Sejarah membuktikan bahwa negara-negara maju seperti Inggris, Rusia, Jepang, serta Cina menjadi maju karena negara-negara tersebut membangun pondasi pembangunannya melalui sektor pendidikan. Mereka membangun sistem pendidikan yang berkualitas. Pendidikan yang bermutu akan menghasilkan sumber daya manusia yang bermutu, dalam arti kualitas bangsa yang baik. ${ }^{19}$ Sebaliknya rendahnya mutu pendidikan pada suatu negara menyebabkan lemahnya mutu sumber daya manusia negara tersebut. Ini berarti tidak mungkin kita mengharapkan untuk menjadi negara dengan sumber daya manusia unggul tanpa didukung oleh sistem pendidikan yang bermutu baik. Negara-negara maju di dunia ini telah membuktikan bahwa, pendidikan memainkan peran kunci dalam mencerdaskan bangsanya, sehingga mereka menjadi bangsa yang maju dan besar.

${ }^{18}$ Robiatul Awwaliyah, Hasan Baharun, Pendidikan Islam dalam Sistem Pendidikan Nasional (telaah epistemology terhadap problematika pendidikan Islam. Jurnal Didaktika Vol. 19, No. 19, h. 43

${ }^{19}$ Halik, A. (2013). Dialektika Filsafat Pendidikan Islam. Istiqra: Jurnal Pendidikan dan Pemikiran Islam, 1(1). 
Hal tersebut nampaknya sangat disadari oleh pemerintah saat ini. Konsep Indonesia Maju dicetuskan oleh Joko Widodo pada periode kedua pemerintahannya, hal tersebut terlihat dalam penutup pidato pelantikan presiden yang menyebutkan bahwa "Layarku sudah terkembang... Kemudiku sudah terpasang... Kita bersama Menuju Indonesia maju...,20

Presiden Joko Widodo juga menyebutkan dalam pidatonya bahwa "Cita-cita kita di tahun 2045 pada satu abad Indonesia merdeka mestinya, Insya Allah, Indonesia telah menjadi negara maju" ${ }^{21}$ Cita-cita tersebut tentu saja hanya bisa diwujudkan melalui pembangunan sumber daya manusia yang menjadi fokus utama pemerintah saat ini. Selanjutnya, Pembangunan sumber daya manusia tentunya hanya bisa dicapai melalui pendidikan yang berkualitas. Langkah nyata yang dilakukan oleh pemerintah terkait peningkatan kualitas pendidikan terutama kaitannya dengan pendidikan Islam adalah diresmikannya Undang-Undang Pesantren pada tanggal 24 September 2019. Menurut Ketua Komisi VIII Dr. Ali Taher Parasong bahwa pesantren adalah lembaga pendidikan khas Indonesia yang memiliki kontribusi nyata dalam sejarah peradaban Indonesia, sehingga dengan pengesahan undang-undang pesantren adalah bentuk aprisiasi dan penghormatan negara terhadap pesantren. ${ }^{22}$ Pondok pesantren merupakan salah satu solusi alternative bagi pengembangan kualitas sumber daya

${ }^{20}$ Artikel ini telah tayang di Kompas.com. Penulis Nur Rohmi Aida Editor : Resa Eka Ayu Sartika,"Pidato Pelantikan dan Kabinet Jokowi, Pengamat: Akan Mudah Reshuffle", diakses pada tanggal 29 November 2019 https://www.kompas.com/tren/read/2019/10/21/193000465/pidato-pelantikan-dan-kabinetjokowi-pengamat--akan-mudah-reshuffle?page=all, Diakases tanggal 29 November 2019

${ }^{21}$ Artikel ini telah tayang di Tribunjambi.com. Editor: Duanto "Salinan Naskah Pidato Presiden Jokowi saat Pelantikan Periode 2019-2024, Daftar Poin Penting 5 Tahun” https://jambi.tribunnews.com/2019/10/21/salinan-naskah-pidato-presiden-jokowi-saatpelantikan-periode-2019-2024-daftar-poin-penting-5-tahun. Diakases tanggal 29 November 2019

${ }^{22}$ Artikel ini telah tayang di Tribunnews.com Editor: Husein Sanusi "UndangUndang Pesantren Resmi Disahkan, Kiai Amal Fathullah Zarkasyi Ajak Semua Elemen Bersyukur" https://www.tribunnews.com/nasional/2019/09/24/undang-undang-pesantrenresmi-disahkan-kiai-amal-fathullah-zarkasyi-ajak-semua-elemen-bersyukur, Diakases tanggal 29 November 2019 
manusia seutuhnya yang selaras dengan semangat cita-cita pendidikan nasional. $^{23}$

Optimalisasi kontribusi pendidikan Islam terhadap menuju Indonesia maju sebagaimana cita-cita kita ditahu 2015 dapat dicapai jika semua pihak memberikan kontribusi yang nyata. Mulai dari pengelola pendidikan baik negeri maupun swasta. Pendidikan harus dikelola dengan professional yang berorientasi pada kualitas pendidikan sesuai dengan tujuan pendidikan dalam Sisdiknas yakni menciptakan manusia yang bermartabat dan berakhlak mulia. Selain itu, Pemerintah juga dituntut untuk berkomitmen dan bersungguh-sungguh serta berpihak pada kemajuan pendidikan. Pendidikan merupakan investasi jangka Panjang yang sangat bernilai untuk menentukan peningkatan kualitas bangsa Indonesia, guna mewujudkan bangsa dan negara Indonesia maju. ${ }^{24}$

Hal tersebut ditegaskan Joko Widodo dalam pidatonya yang menyatakan bahwa "Namun, semua itu tidak datang otomatis, tidak datang dengan mudah. Harus disertai kerja keras, dan kita harus kerja cepat, harus disertai kerja-kerja bangsa kita yang produktif." 25 Berbagai problem yang dihadapi dalam mengembangkan pendidikan Islam, di antaranya adalah kurikulum, sumber daya manusia, ${ }^{26}$ sarana dan prasarana, anggaran, kemitraan, dan seterusnya. Kesemua itu menjadi bagian dari tugas pemerintah untuk meminimalisir kelemahan dan kekurangan pendidikan Islam agar tetap survive di tengah revolusi industry 4.0.

${ }^{23}$ Halik, A. (2016). Paradigm of Islamic Education in the Future: The Integration of Islamic Boarding School and Favorite School. Information Management and Business Review, 8(4), 24-32.

${ }^{24}$ Muhardi, Kontribusi Pendidikan Dalam Meningkatkan Kualitas Bangsa Indonesia, Jurnal mimbar, Volume XX No. 4 Oktober - Desember 2004, h. 491

${ }^{25}$ Artikel ini telah tayang di Tribunjambi.com. Editor: Duanto "Salinan Naskah Pidato Presiden Jokowi saat Pelantikan Periode 2019-2024, Daftar Poin Penting 5 Tahun" https://jambi.tribunnews.com/2019/10/21/salinan-naskah-pidato-presiden-jokowi-saatpelantikan-periode-2019-2024-daftar-poin-penting-5-tahun?page=2. Diakases tanggal 29 November 2019

${ }^{26}$ Hanafie, S. W., Dangnga, M. S., Halik, A., \& Rahmah, J. (2019). Problems of Educators and Students in Learning Islamic Religious Education at MTs Pondok Darren Modern Darul Falah, Enrekang District. Al-Ulum, 19(2), 360-386. 


\section{KESIMPULAN}

Sejarah pendidikan Islam di Indonesia berarti berbicara tentang sejarah kebijakan pemerintah Indonesia mulai dari masa orde lama, orde baru, hingga reformasi. Berdasarkan penelusuran sejarah, kebijakan pemerintah tiap masa pemerintahan mengalami perkembangan dan terlihat keberpihakan pemerintah terhadap pendidikan Islam melalui Sistem Pendidikan Nasional.

Kedudukan pendidikan Islam dalam sistem pendidikan nasional dapat dilihat dari tiga hal yakni pendidikan Islam sebagai lembaga pendidikan, pendidikan Islam sebagai mata pelajaran dan Pendidikan Islam sebagai sistem nilai. Selain itu kedudukan pendidikan Islam semakin kuat terlihat pada pasal 12 yang menekankan hak pengajaran Pendidikan Agama kepada peserta didik, serta pasal 37 ayat 1 tentang muatan wajib kurikulum di sekolah yang salah satunya adalah Pendidikan Agama dalam sistem pendidikan Nasional.

Adapun kontribusi pendidikan Islam menuju Indonesia maju dapat terlihat dalam lintasan sejarah pendidikan Islam di Indonesia, posisi strategis pendidikan Islam dalam Sistem Pendidikan Nasional, serta prioritas program pemerintah saat ini tentang pembangunan sumber daya manusia yang tentu saja hanya bisa dicapai melalui peningkatan kualitas pendidikan tak terkecuali pendidikan Islam yang merupakan ruh dari Sistem Pendidikan Nasional saat ini.

\section{DAFTAR PUSTAKA}

Awwaliyah, Robiatul. Baharun, Hasan. 2018. Pendidikan Islam dalam Sistem Pendidikan Nasional (telaah epistemology terhadap problematika pendidikan Islam. Jurnal Didaktika Vol. 19, No. 19

Azra, Azyumardi. 2014. Pendidikan Islam; Tradisi dan Modernisasi di tengah Tantangan Millenium III. Cetakan ke-2; Jakarta: Kencana 
Daulay, Putra, Haidar. 2012. Pendidikan Islam dalam Sistem Pendidikan Nasional di Indonesia. Jakarta: Kencana Prenada Group

Duanto "Salinan Naskah Pidato Presiden Jokowi saat Pelantikan Periode 2019-2024, Daftar Poin Penting 5 Tahun" Diakases tanggal 29 November 2019 https://jambi.tribunnews.com/2019/10/21/salinannaskah-pidato-presiden-jokowi-saat-pelantikan-periode-2019-2024daftar-poin-penting-5-tahun.

Gani, Ali, Hasniyati, St. 2015. Kebijakan Pemerintah terhadap Pembinaan Pendidikan Islam. Jurnal Al-Ta'dib Vol. 8 No. 2, Juli-Desember

Halik, A. (2013). Dialektika Filsafat Pendidikan Islam. Istiqra: Jurnal Pendidikan dan Pemikiran Islam, 1(1).

Halik, A. (2016). Paradigm of Islamic Education in the Future: The Integration of Islamic Boarding School and Favorite School. Information Management and Business Review, 8(4), 24-32.

Halik, A. (2016). Paradigma Pendidikan Islam dalam Transformasi Sistem Kepercayaan Tradisional. AL-ISHLAH: Jurnal Pendidikan Islam, 14(2).

Hanafie, D., \& Hali, A. (2015). Masalah Putus Sekolah Dan Pengangguran.

Hanafie, S. W., Dangnga, M. S., Halik, A., \& Rahmah, J. (2019). Problems of Educators and Students in Learning Islamic Religious Education at MTs Pondok Darren Modern Darul Falah, Enrekang District. AlUlum, 19(2), 360-386.

https://id.wikipedia.org/wiki/Orde_Lama, diakses tanggal 7 November 2019

Husein Sanusi "Undang-Undang Pesantren Resmi Disahkan, Kiai Amal Fathullah Zarkasyi Ajak Semua Elemen Bersyukur" Diakases $\begin{array}{lll}\text { tanggal } & 29 & \text { November }\end{array}$ 
https://www.tribunnews.com/nasional/2019/09/24/undang-undangpesantren-resmi-disahkan-kiai-amal-fathullah-zarkasyi-ajak-semuaelemen-bersyukur,

Ismail. 2016. Politik Pendidikan Islam Orde Lama 1945-1965 (Study Kebijakan Pemerintah dalam Penyelenggaraan Pendidikan Islam), Jurnal Kabilah Vol. 1 No. 1 Juni

Jannah, Miftahol. Saputra, Adi, Bachtiar. Sya'adah, Aminatus. Mahfud, Choirul. 2019. Sejarah reformasi pendidikan Islam di Indonesia, Ta'dibuna Vol.8 No.1, April

Kosim, Mohammad. 2014. Kebijakan Pendidikan Agama Islam di Sekolah pada Masa Orde lama, Jurnal Karsa, Vol. 22 Nomor 1, Juni

Mubarak, Faisal. 2015 Perkembangan Kebijakan Pendidikan Islam Indonesia, Jurnal: Ta'lim Muta'allim, Vol. 4, No. 8

Muhardi. 2004. Kontribusi Pendidikan Dalam Meningkatkan Kualitas Bangsa Indonesia, Jurnal mimbar, Volume XX No. 4 Oktober Desember 2004

Nata, Abuddin. 2005. Manajemen Pendidikan: Mengatasi Kelemahan Pendidikan di Indonesia. Jakarta: Kencana

Nata, Abuddin. 2016. Ilmu Pendidikan Islam. Cetakan ke-3; Jakarta: Kencana

Nur Rohmi Aida, Resa Eka Ayu Sartika,"Pidato Pelantikan dan Kabinet Jokowi, Pengamat: Akan Mudah Reshuffle", diakses pada tanggal 29 November

https://www.kompas.com/tren/read/2019/10/21/193000465/pidatopelantikan-dan-kabinet-jokowi-pengamat--akan-mudahreshuffle?page $=$ all, 
Nursyarif, Aisyah. 2014. Pendidikan Islam di Indonesia dalam Lintasan Sejarah (Perspektif Kerajaan Islam). Jurnal Lentera Pendidikan Vol. 17 No.2 Desember

Rofi, Sofyan. 2016. Sejarah Pendidikan Islam di Indonesia. Jakarta; Deepublish 